\title{
Childhood Testicular Neoplasm
}

National Cancer Institute

\section{Source}

National Cancer Institute. Childhood Testicular Neoplasm. NCI Thesaurus. Code C5053.

A neoplasm that arises from the testis during childhood. 